\title{
The present status of marine fish cultivation research in Japan
}

\author{
T. HARADA \\ Fisheries Laboratory of Kinki University; Shirahama, Wakayamaken, Japan
}

KURZFASSUNG: Der gegenwärtige Stand der Züchtungsforschung an Meeresfischen in Japan. Der derzeitige Stand der Forschungsarbeiten über die Zucht von Meeresfischen in Japan wird kurz umrissen. Der Ertrag an kommerziell gezüchteten Fischen betrug 1967 mehr als 27000 t. Die Zucht erfolgt in Netzkäfigen oder auch in Fischteichen (vorwiegend im Südwesten Japans). Zu den wichtigsten züchtbaren Fischen gehören die Arten Seriola quinqueradiata, Fugu rubripes und Pagrus major. Es werden die Methoden der Laichgewinnung, der Erbrütung und Aufzucht dargestellt sowie einige Probleme der Ernährung, der Bekämpfung von Krankheiten und der Hybridisierung von Meeresfischen behandelt.

\section{INTRODUCTION}

Stocks in Japanese fish farms are usually recruited from young fish caught at sea; but recently, in some species, artificially reared fry are more and more taking the place of natural young fish. Species of cultivated fishes in Japanese farms are yellow-tail Seriola quinqueradiata, amber jack Seriola purpurescens, striped jack Longirostrum delicatissimus, puffer Fugu rubripes rubripes, red sea bream Pagrus major, black sea bream Acanthopagrus schlegelii, Silver bream Sparus sarba, Japanese parrot fish Oplegnatbus fasciatus, spotted parrot fish Oplegnatbus punctatus, and bastard halibut Paralichthys olivaceus.

In 1967, the production of cultivated marine fishes in Japan amounted to 27,103 tons in gross weight (Table 1), worth $8,669,000,000$ yen $(24,080,555$ U.S. dollars; Table 2). The production consisted of $98.6 \%$ (26,712 tons) yellow tails, $0.25 \%$

Table 1

Production of cultivated marine fishes in Japan (1964-1967) in tons

\begin{tabular}{|lrrrr|}
\hline Species & 1964 & 1965 & 1966 & 1967 \\
\hline Yellow-tail & 9,493 & 18,083 & 19,629 & 26,712 \\
Puffer & 86 & 91 & 82 & 53 \\
Other fishes & 116 & 101 & 328 & 338 \\
\hline$\Sigma$ & 9,695 & 18,275 & 20,039 & 27,103 \\
\hline
\end{tabular}


Table 2

Value of cultivated marine fishes in Japan (1964-1967) in 1,000 Dollars

\begin{tabular}{|lrrrr|}
\hline Species & 1964 & 1965 & 1966 & 1967 \\
\hline Yellow-tail & 8,356 & 15,178 & 18,972 & 23,483 \\
Puffer & 358 & 233 & 264 & 153 \\
Other fishes & 56 & 86 & 311 & 444 \\
\hline$\Sigma$ & 8,770 & 15,497 & 19,547 & 24,080 \\
\hline
\end{tabular}

(53 tons) puffers, and $1.2 \%$ (338 tons) of other marine fishes. Some of the latter, including amber jack, striped jack, red sea bream and Japanese parrot fish, are now receiving increased attention in many fish farms.

\section{RESULTS AND CONCLUSIONS}

The larger part of the fishes are cultivated in floating net cages set in sheltered places; the rest are cultivated in fish ponds (sheltered places partitioned from the sea with nets or banks).

Most marine fish farms in Japan are concentrated in the area along the southwest coast. This area is influenced by the warm current. The highest water temperature in the farms is $25^{\circ}-31^{\circ} \mathrm{C}$ in summer; the lowest, $5^{\circ}-16^{\circ} \mathrm{C}$ in winter. The difference in level between the high and low tides is $50-300 \mathrm{~cm}$ on the Pacific coast of Japan, but $20-30 \mathrm{~cm}$ only on the coast of the Japan Sea. As the water exchange in fish farms depends almost entirely upon the tidal current and the movements of the fish, the farms on the Japan Sea coasts are somewhat at a disadvantage.

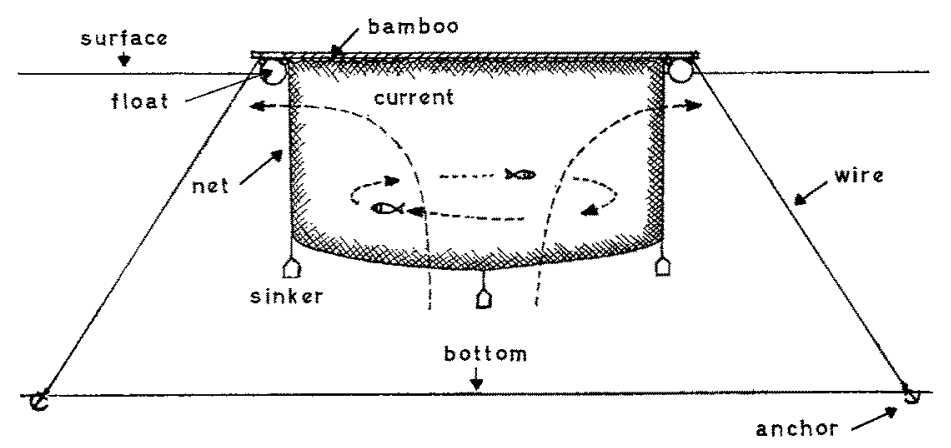

Fig. 1: Section of a floating net cage

In 1954, I tried fish cultivation in floating net cages for the first time and since 1957 the application of this method has rapidly increased in Japan. Rafts are necessary for floating net cultivation. Materials needed are: nets, some bamboo (or wood), floats, wires and anchors. The raft is made of bamboo (or wood) and floats set in either a square or circular outline. Sometimes the raft is used without bamboo or wood. For 
convenience, a few to a dozen squares are constructed jointly into a big raft. Then the net cage is hung down from the raft, or from each square unit of big rafts, to hold young fishes for cultivation. The net cage is usually stretched with a single layer of net, but,

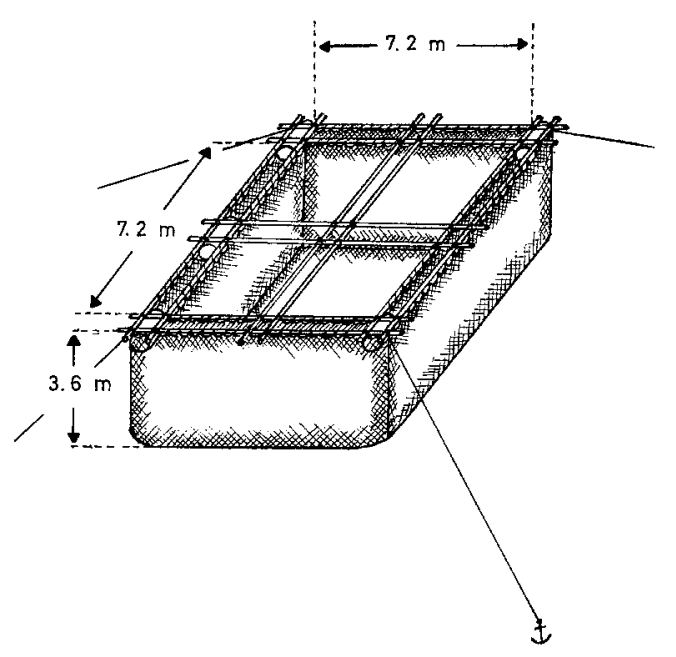

Fig. 2: Floating net cage stretched with double layers of net

sometimes, with double layers of net for protection against damages. The nets used for cultivation are made of synthetic fibres and this makes marine fish cultivation economic. The raft is usually anchored, but it can be moved or lowered to deeper levels

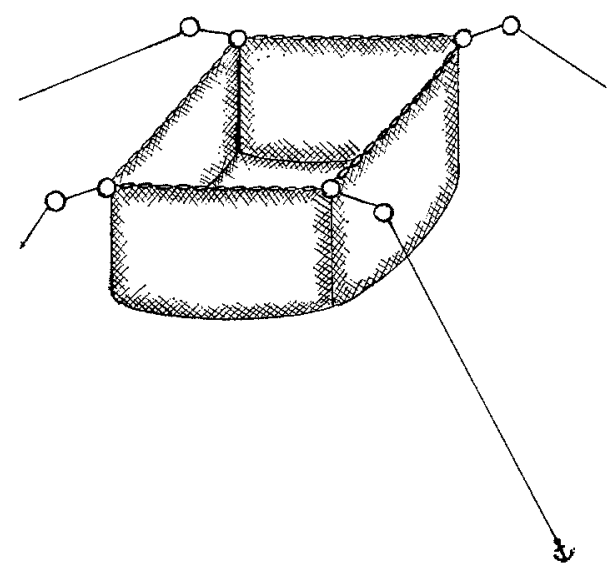

Fig. 3. Floating net cage kept afloat by floats only, without bamboo or wood

complete with fishes as desired. The area of the net cage varies from 4 to $400 \mathrm{~m}^{2}$ and the depth of the cage from $2-15 \mathrm{~m}$. Roughly 10 to $80 \mathrm{~kg}$ of young fish are cultivated per $\mathrm{m}^{2}$.

This cultivation method has many advantages over pond cultivation. The sea area 
available for fish farms has been increased by employing the floating net-cage method, but this has caused progressive contamination of the area used for farming fishes from year to year. In order to counteract this first serious problem, contamination of the farm; studies to accelerate the water exchange in the farm area, to remove bottom deposits and to make net-cage farming possible in deep water are now in progress.

The food used for cultivated marine fish consists mostly of fresh or refrigerated fishes, such as sand eel Ammodytes personatus, anchovy Engraulis japonica, horse mackerel Trachurus japonicus, saury Cololabis saira and the common mackerel Scomber japonicus. The required increase in the production of these food fishes cannot be expected to be easily achieved. Hence, for the years to come, no one can ensure a sufficient quantity of food fishes to provide for all cultivated fishes in Japan. To overcome this second serious problem, studies have been initiated in Japan with the aim of replacing fresh or refrigerated food fishes by artificial fish food. Utilization of some products from soya beans, dry white fish meal and yeasts cultivated on waste petroleum or wood pulp is being tested with great interest. Furthermore, the required balance between protein, fat and vitamins needed for the growth of the fishes to be cultivated is subject to investigation.

The mass cultivation of marine fishes has inevitably caused the prevalence of various fish diseases in the farms. Studies to prevent or cure such diseases have now been started. Devices for removing the skin parasite Benedenia seriolae, the gill parasite Heteraxine heterocerca, and the oral-cavity parasite Caligus amplifurcus have been developed. Cures for infections caused by bacteria such as Vibrio sp. or of some diseases caused by nutritional disorder have been worked out. In spite of such successes unknown types of disease appear one after another and, sometimes, they are fatal to the fishes in cultivation. In order to counteract this third serious problem new diseases are now intensively studied. The total numbers of young fish caught at sea for cultivation purposes, are very low, except for the yellow-tail. Sometimes even the number of young yellow-tail caught at sea is not sufficient to supply all farms. Moreover, in order to conserve the natural resources of yellow-tail, the Japanese government has limited the number of young fish which may be supplied to all farms in the country to $28,360,000-30,780,000$ per year. Thus, even in the case of the yellow-tail, for increased production of cultivated fish, the farm stocks must be recruited from young individuals reared artificially from eggs. To overcome this most essential problem, studies on artificial production of young of important marine fishes are now in progress.

To increase the natural resources in the Inland Sea of Japan, the Association of Marine Stock Farm of the Seto Inland Sea was incorporated in 1963. It has just started mass release of artificially produced young of some fish species. The numbers of artificially produced young marine fishes released in 1968 were: 166,686 red sea bream $P a-$ grus major and 125,536 scorpion fish Sebastiscus marmoratus. 'The effects of such releases of young fish on the natural resources are now being investigated. The most urgent work to be done is to protect the released young fishes from enemies, including fishermen, and from unfavourable environmental circumstances. If this can be achieved in some way, then the release of artificially produced young fishes will be extended to more extensive areas of the sea. Evidently, however, a great number of young fish will 
be needed for effective increase of the natural resources. To achieve this purpose artifcial mass production of young fish is indispensable.

For the mass production of young marine fishes, a continuous supply of adequate amounts of ripe eggs is essential. Ripe eggs are obtainable not only from fishes caught at sea but also from fishes reared in farms. In the latter case, eggs are more easily obtained and with greater certainty; in addition, the hatching rate in eggs from reared

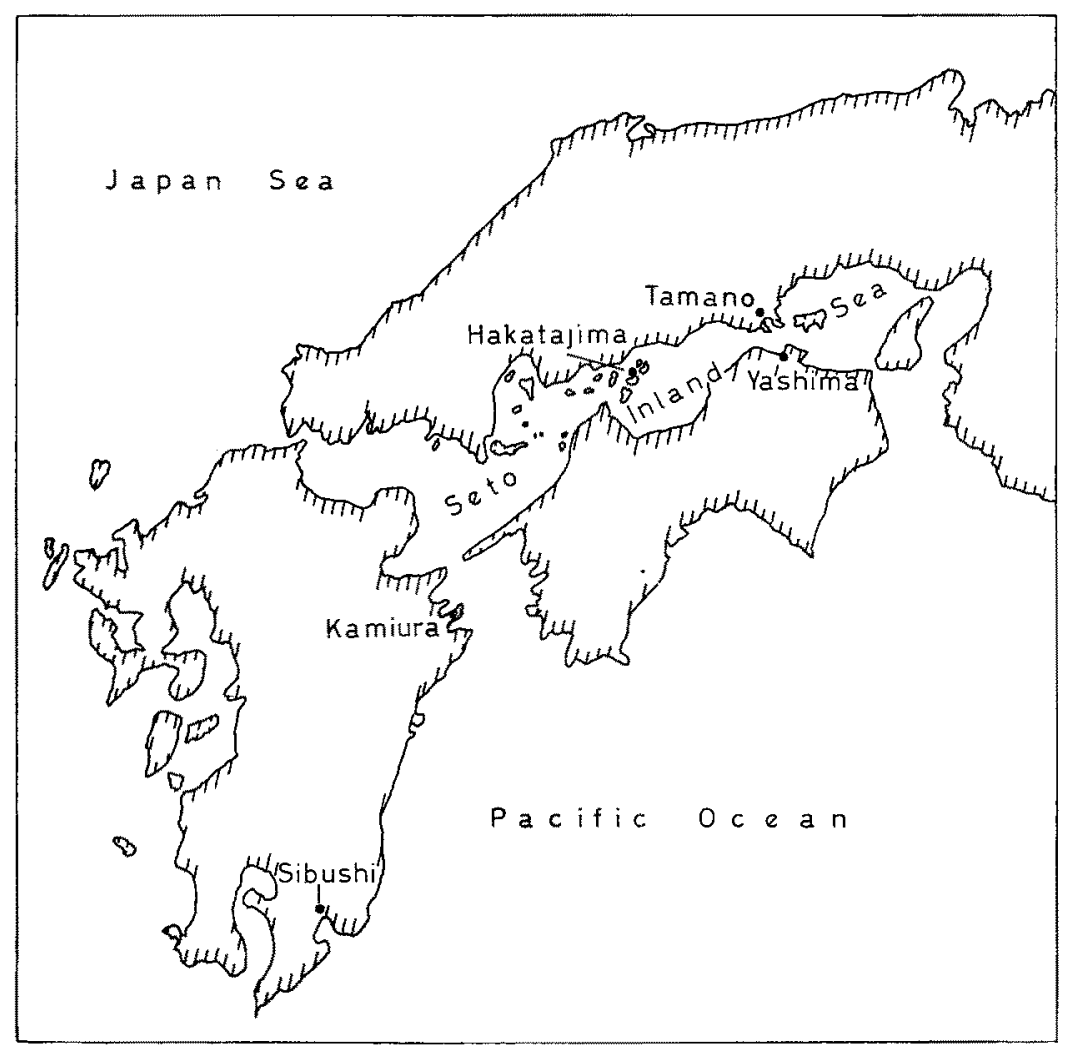

Fig. 4: Localities of farms maintained by the Association of Marine Stock Farm of the Seto Inland Sea

fishes is generally higher than in those from fishes caught at sea. The devices for obtaining ripe eggs from reared fish have been developed successfully in some fishes such as red sea bream, black sea bream, silver bream, yellow-tail, Japanese parrot fish and bastard halibut. Mature individuals of such fishes are reared and are made to spawn in floating net cages set in sheltered places or in tanks of a laboratory aquarium. Sometimes hormones or vitamin $E$ are injected intramuscularly to promote sexual maturity. At present, eggs from reared yellow-tail are obtained by this method only.

For successful raising of adult fishes to maturity, it is most important to maintain the following three conditions: (1) favourable breeding environment, (2) balanced 
nutrition, and (3) healthy condition of fishes. Although ripe eggs are available from some important cultivated marine fishes, no eggs have yet been obtained from many others. In order to harvest ripe eggs from the latter, and to obtain more eggs with higher hatching rates from the former, further crucial studies are being made on the rearing conditions required by mature individuals of the respective species.

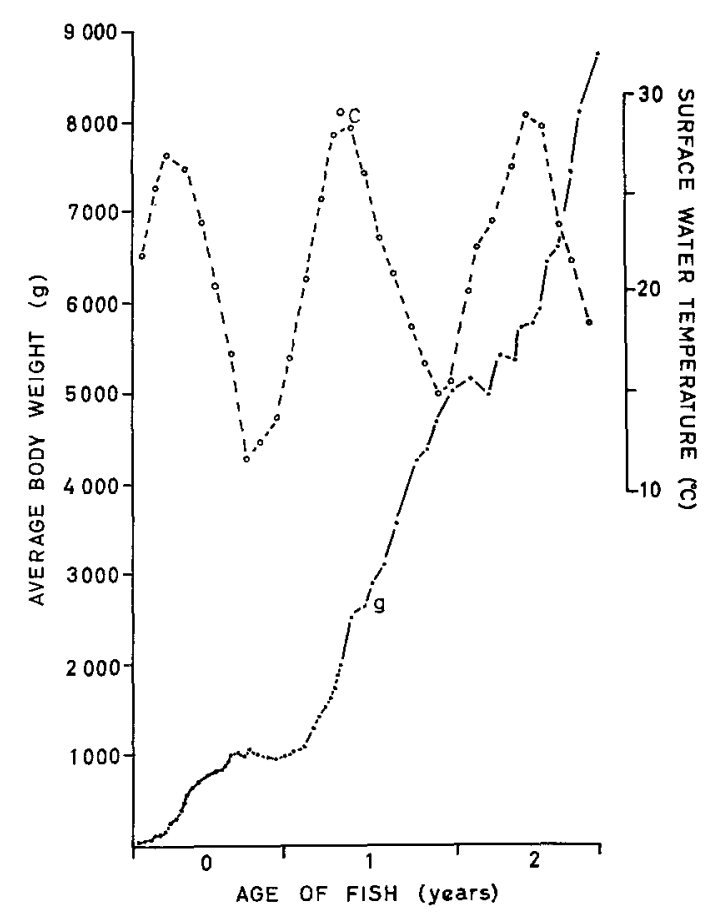

Fig. 5: Growth of cultivated yellow-tail

Spawning, fertilisation, hatching and raising to commercial size have been achieved experimentally in several important shallow water marine fishes such as yellow-tail, red sea bream, black sea bream, silver bream, Japanese parrot fish, puffer and bastard halibut.

For the fertilization of eggs, the dry method is usually adopted, except for puffer, though sometimes the wet method is employed. Circular or square tanks, or net cages, are used to incubate the eggs and to rear the fry. The water in the incubator on rearing tank of fry should be changed very. slowly, or may be left unchanged for a few days. The afore-mentioned fishes, except puffer, hatch 2 to 3 days after insemination within suitable temperature ranges.

The sea-water in tanks or net cages must be filtered, moved and changed to keep the ambient water suitable for hatching and rearing of fry. Chlamydomonas sp. and Chlorella sp. are used to remove the metabolic wastes of fry and to supply oxygen. Aeration is effected both via supplying oxygen and inducing water movement. The 
environment conditions exactly suitable to respective developmental stages of eggs and fry are being studied.

Research has been conducted on suitable food for respective developmental stages and on possible ways of producing or preparing such food. Fry of the afore-mentioned fishes begin to take food 3 to 5 days after hatching. The first food for fry consists of larvae of oyster (which can be cultivated in quantity) or sea urchin. Oyster larvae are consumed for 2 to 5 days. The second food is the rotifer Brachionus plicatilis which is

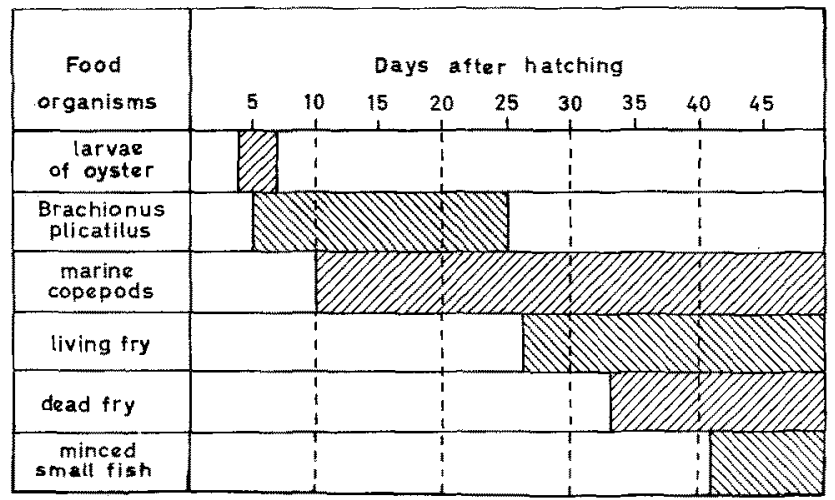

Fig. 6: Food succession of young marine fishes in cultivation

consumed 4 to 25 days after hatching. The rotifer can also be cultivated in quantity. The third food source comprises marine calanoid and cyclopoid copepods, cultivated harpacticoids Tigriopus japonicus, or nauplii of Artemia salina. Of these, marine calanoid and cyclopoid copepods represent, apparently, the best food. Young fishes eat them from 8 to 100 days after hatching. The fourth food source includes fry of other fishes or mysids and shrimp larvae which are generally taken 20 to 25 days after hatching. The fifth, and last, food source is minced fish which is taken by fry 30 to 60 days after hatching. Tigriopus japonicus and Artemia salina can be cultivated in quantity, but do not seem to make a perfect food for sufficient growth of the fishes cultivated.

Research for food sources more suitable to the respective developmental stages of fishes and cultivation studies on marine copepods of higher nutritive value are now in progress.

Internal and external diseases of young fishes have been studied in order to keep them healthy and increase the survival rate. It is much more difficult to prevent or cure diseases of young fish than of adult fish.

Some experiments which aim to produce hybrids among marine fishes are in progress. Several hybrids have been produced artificially and reared successfully; for instance, between female red sea bream and male black sea bream, female red sea bream and male silver bream, female Japanese parrot fish and male black sea bream, and between female Fugu rubripes rubripes and male Fugu xantbopterum. Characteristics of hybrids thus produced are now being investigated by rearing experiments.

Thus, in Japan various research projects concerned with marine fish cultivation are in progress. It is our hope to rear more and more marine fishes artificially through- 
out their whole life history in order to supply the growing human population with sufficient amounts of marine fish products.

\section{SUMMARY}

1. The present status of marine fish cultivation research in Japan is reviewed.

2. In marine fish farms, the stocks have been recruited from young fish caught at sea, but recently, artificially reared fry are more and more taking the place of natural young fish, in some species.

3. The main fish species cultivated in Japanese farms are yellow-tail Seriola quinqueradiata, puffer Fugu rubripes rubripes and red sea bream Pagrus major; they are mostly cultivated in floating net cages set in sheltered places.

4. To increase the natural resources, the release of artificially reared young of some fishes has just started in the Inland Sea of Japan.

5. Efforts are being made to obtain ripe eggs from reared marine fishes, to hatch fertilized eggs and to raise fry: Spawning, fertilization, hatching and raising to commercial size has been achieved in several important shallow water marine fishes.

6. To keep the ambient water suitable for hatching and raising of fishes, filtration, circulation, exchange of sea water and availability of Chlamydomonas sp. and Cblorella sp. (to remove metabolic wastes of the fish and to supply oxygen) have been studied.

7. Research on food sources suitable for respective stages of fishes and on the methods of producing such foods have been made. Several marine organisms are cultivated in abundance as food sources for fishes.

8. Diseases of marine fishes have been studied to keep them healthy and to enhance survival rates.

9. Some experiments on the production of hybrids between different marine fish species are now in progress; several hybrids have already been produced artificially and reared successfully.

\section{LITERATURE CITED}

HARADA, T., 1965. Studies on propagation of yellow-tail (Seriola quinqueradiata T. et S.). With special reference to relationship between feeding and growth of fish reared in floating net crawl. Mems Fac. Agric. Kinki Univ. 3, 1-291.

Hushimi, T., 1968. Studies on production of young fish of the red sea bream (Pagrus major). Effects of a few kinds of food upon the growth and survival rates of fry. Rep. Fish. exp. Sta. Hirosbimaken 1, 49-54.

Iто, T., 1960. On the culture of mixohaline rotifer Brachionus plicatilis O. F. MrLLer in the sea-water. Rep. Fac. Fish. prefect. Univ. Mie 3, 708-740.

Statistical year-book of fishery and fish cultivation products, 1967. Publ. by the Dept of Agriculture and Forestry. Statistics of Agriculture and Forestry Association, Tokyo, $395 \mathrm{pp}$.

Author's address: Professor Dr. T. Harada

Fisheries Laboratory of Kinki University

Shirahama, Wakayamaken, 649-22, Japan 